\title{
高張力鋼のスポット溶接継手の三次元的疲労き裂進展挙動観察*
}

\author{
種子島亮太 ${ }^{* 1}$, 曙 紘 之 ${ }^{* 2}$, 加 藤 昌 彦*2 \\ 宮 坦 亜 希*3, 菅田 淳*2
}

\section{3-Dimensional Observation of Fatigue Crack Propagation on Spot Welded Joints Using High Strength Steel}

\author{
Ryota TANEGASHIMA*4, Hiroyuki AKEBONO, Masahiko KATO, \\ Aki MIYAGAKI and Atsushi SUGETA \\ ${ }^{* 4}$ Department of Mechanical System Engineering, Hiroshima University, \\ 1-4-1 Kagamiyama, Higashi-Hiroshima-shi, Hiroshima, 739-8527 Japan
}

\begin{abstract}
Recently, it has been demanded to develop the lightened automobile with high stiffness and strength for the fuel economy and the vehicle safety performance. Therefore, it has been considered to apply the ultra high strength steel. A few reports indicate the fatigue strength of the spot welded joint using the high strength steel was not improved compared with the conventional mild steel. Moreover, it has been investigated the proper number of spot and the arrangement which were regarded the strength reliability for the energy saving and the cost reduction. In order to solve these problems, it is important to acquire the knowledge about the fatigue characteristics of spot welded joint. In this study, in order to investigate the fatigue characteristics, fatigue tests were conducted under the shear loading condition and internal fatigue crack behavior around the spot area was observed in detail. Test results showed that spot welded joints had the low fatigue strength compared with the strength of base metal. Additionally, specimens indicated the different fracture types; button fracture and base metal fracture. Then, 3-dimensional observation of the fatigue crack propagation was conducted on each fracture type. As this result, it was clarified spot welded joints used in this study require many cyclic loading to initiate the fatigue crack around the spot area. Furthermore their fatigue crack propagation indicates the similar behavior in major part of life independently of the stress level.
\end{abstract}

Key Words: Fatigue, Crack Propagation, Welded Joint, High Strength Steel, 3-Dimensional Observation

\section{1. 緒言}

近年, 自動車産業分野では燃費向上および衝突安全 性の観点から軽量かつ高剛性・高強度を有する車体開 発が望まれている。これらの要望に応えるため, 車体 の主材料である鋼板の高強度化が進み, 超高張力鋼板 の導入も検討され始めている(1)(2). しかしながら, 母 材強度の上昇に反し，それらにスポット溶接を施した 継手部の疲労強度は, 従来鋼板と比較して同程度, ま たはそれ以下であることが報告されており，同材の適 用範囲拡大における大きな問題となっている。

また，自動車産業分野では，それらの自動化の容易 さや作業性の高さからスポット溶接を多用しており， その施工数は車 1 台あたり約 $4000 〜 5000$ 点と言われ

* 原稿受付 2010 年 2 月 19 日.

*1 学生員, 広島大学大学院工学研究科(画 739-8527 東広島市 鏡山 1-4-1).

*2 正員, 広島大学大学院工学研究科.

*3 正員, (株) コベルコ科研(ङ 651-2271 神戸市西区高塚台 15-5)

E-mail : M080357@ hiroshima-u.ac.jp
ているが, 近年の地球環境問題を考慮すれば,スポッ 卜溶接施工数を削減することによって，自動車製造現 場における省エネルギー化，コスト削減，および生産 性向上を目指す取組は必要不可欠であり，それらを実 現するために強度信頼性を考慮した適正な溶接施工 数，およびその配列について検討することは重要な課 題となってきている.このような背景からスポット溶 接継手の疲労特性に関する知見の重要性が高くなって きているが，これまでの研究報告の多くはその疲労寿 命推定に重きが置かれており(3) (11), 疲労特性に関す る報告例は僅少(12)(13) であるため未だに不明な点が多 いのが現状である.

そこで本研究では一般的な自動車用鋼として用いら れている高張力鋼 (590 MPa 級)を母材とするスポッ 卜溶接継手を用い, その疲労特性, および破壊メカ二 ズムを実験的に明らかにすることを目的とした。ささ に，スポット部近傍に生じる微小疲労き裂の 3 次元的 観察，およびそれに伴うひずみ挙動について検討，考 察を加えた。 
Table 1 Chemical composition of SPFC590Y [mass\%]

\begin{tabular}{|c|c|c|c|c|c|c|}
\hline Material & $\mathrm{C}$ & $\mathrm{Si}$ & $\mathrm{Mn}$ & $\mathrm{P}$ & $\mathrm{S}$ & $\mathrm{Fe}$ \\
\hline SPFC590Y & 0.06 & 0.63 & 1.61 & 0.009 & 0.004 & Bal. \\
\hline
\end{tabular}

Table 2 Mechanical properties of SPFC $590 \mathrm{Y}$

\begin{tabular}{|c|c|c|}
\hline $\begin{array}{c}0.2 \% \text { proof stress } \\
(\mathrm{MPa})\end{array}$ & $\begin{array}{c}\text { Tensile stress } \\
(\mathrm{MPa})\end{array}$ & $\begin{array}{c}\text { Elongation } \\
(\%)\end{array}$ \\
\hline 354 & 612 & 28 \\
\hline
\end{tabular}

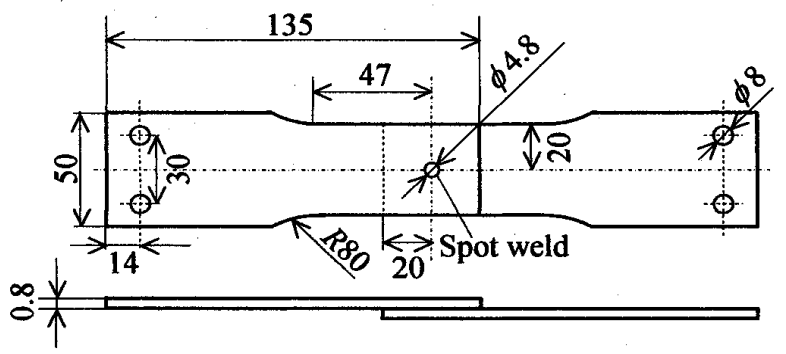

Fig. 1 Shape of specimen and dimension

\section{2. 供試材料および実験方法}

$2 \cdot 1$ 供試材料 母材には一般的自動車用鋼とし て使用されている低降伏比型の冷間圧延高張力鋼板 SPFC $590 \mathrm{Y}$ (板厚 $t=0.8 \mathrm{~mm}$ )を用いた。 なお，同材 の化学組成を表 1 に, 機械的性質を表 2 にそれぞれ示 す.

同材を図 1 に示す薄板形状に機械加工後, 2 枚の薄 板をスポット溶接により溶接し供試状態とした。な お，スポット部の溶着部であるナゲット径が $\phi=4.8$ $\mathrm{mm}$ となるよう溶接条件を統一した。

$2 \cdot 2$ 実験方法 引張試験および疲労試験には島 津製作所油圧式サーボパルサーを用いた。この際, 板 厚分平行移動が可能な治具を用いることにより，試験 片取付けの際，スポット部に曲げ応力が作用しないよ うにしている。な报労試験は，室温大気中，周波数 $f=1 \sim 30 \mathrm{~Hz}$, 応力比 $R=0.05$ で行い, 未破断時の試 験打切り回数は $N=10^{7}$ cycles とした.

\section{3. 実験結果および考察}

$3 \cdot 1$ 組織観察および硬さ試験 図 2 にスポット 部中央断面の組織観察結果を示す。同図より, 本試験 体はスポット溶接により接合されたナゲット部, その 周囲の熱影響部(HAZ 部)，执よび母材部に分類され る 3 つの組織領域が存在することがわかる，なお，母

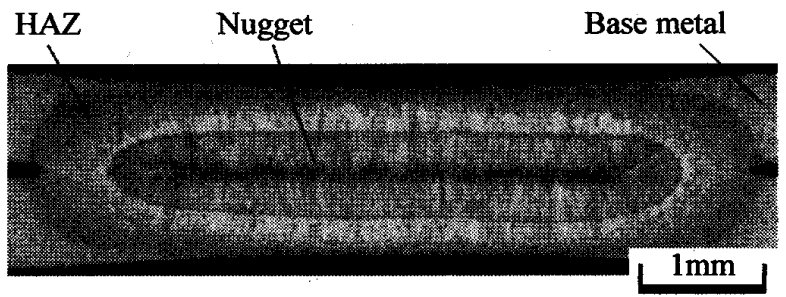

Fig. 2 Microstructure observation at the cross section

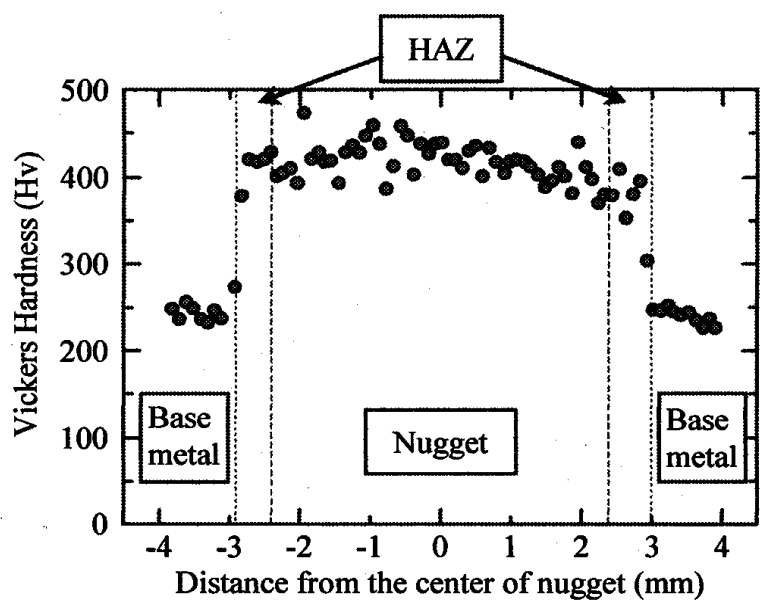

Fig. 3 Hardness distribution in the horizontal direction of nugget

材部からナゲット部中央に近づくに従い, 結晶粒が粗 大化している様子が確認された．また，HAZ 部内の 接合界面において，コロナボンドと呼ばれる圧接部が 確認された。

次に，試験片断面におけるスポット部近傍の硬さを 測定した。結果を図 3 に示す。同図より，ナゲット部 の硬さは母材部の約 1.7 倍程度であり, 顕著な硬度上 昇が確認された。これは冷却過程においてマルテンサ イト組織が生成したためであると考えられる。なお， HAZ 部においてはナゲット部から母材部の領域に近 づくに従い硬度が低下することが認められた。

$3 \cdot 2$ 引張試験結果 静的引張試験を行った結果 を図 4 に示す。なお, 負荷速度は $0.1 \mathrm{kN} / \mathrm{sec} て ゙ あ り$, 縦軸は荷重をスポット溶着部面積で除した公称せん断 応力を示す. また, 横軸は試験体に対するピストン変 位を示す。

同図より, 本試験体の引張強度は $480 \mathrm{MPa}$ 程度で あることがわかる.なお, 同試験を複数の試験片に対 して行った結果, 同様の挙動および強度を示しており, 顕著なばらつきがないことを確認している。

$3 \cdot 3$ 疲労試験結果および破壊形態 図 5 に疲労 試験結果を示す。なお, 本研究で用いたスポット溶接 試験片は繰返し負荷によりスポット部に主にせん断負 荷を受ける形状であることから同図縦軸は負荷荷重を 
スポット溶着部であるナゲット面積で除した公称せん 断応力を用いて整理している.

同図より，本試験体の疲労強度は $\tau_{a}=30 \mathrm{MPa}$ であ り母材部の静的強度 $\left(\sigma_{y}=612 \mathrm{MPa}\right)$ ，および前節に示 した継手の静的強度 $\left(\tau_{y}=480 \mathrm{MPa}\right)$ に比べて著しく低 い値であることがわかる。

次に，破断した全ての試験片の巨視的破壊形態に着 目すると, 図 6 に模式的に示す通り明らかな応力依存 性が確認された。すなわち，比較的高い応力レベルに おいては同図 ( a ) 点において試験片表面に貫通したき 裂がスポット部周囲を進展し，（b ）点に到達した後に 静的破壇を呈する破壊形態であるのに対し，比較的低 い応力レベルにおいては，(a) 点においてき裂が試験 片表面上に貫通した後，スポット部周囲を進展し（c） 点に到達すると荷重軸直角方向へとき裂進展経路を変 え，(d)点にき裂が到達したところで静的破壊を呈す る破壊形態を示した。以降，前者をボタン破壊，後者 を母材破壊と称する。図 7 に疲労試験後の試験体全体

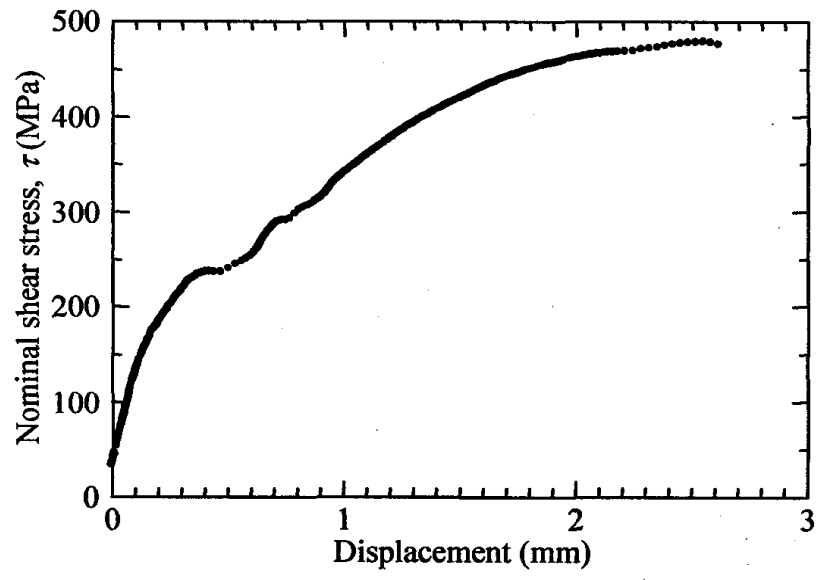

Fig. 4 Stress-displacement curve of spot welded joints

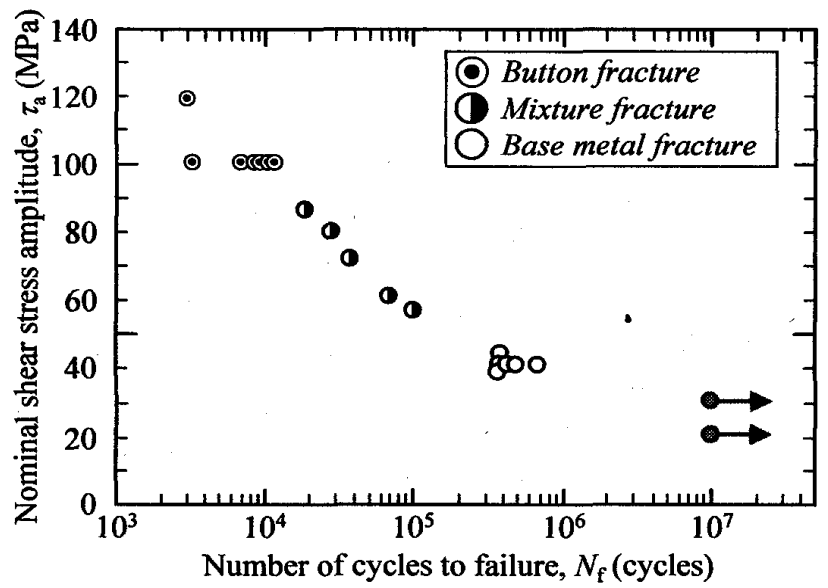

Fig. $5 \quad S-N$ curve
の概観の一例および各破壊形態における巨視的観察結 果をそれぞれ示す。なお，本試験の場合，最終破断時 の大変形によりスポット部が大きく回転するため, 最 終的には同図に示すような巨視的破壊形態となる.

また, 同図 $(\mathrm{d})$ に示すような中間応力レベルでは両

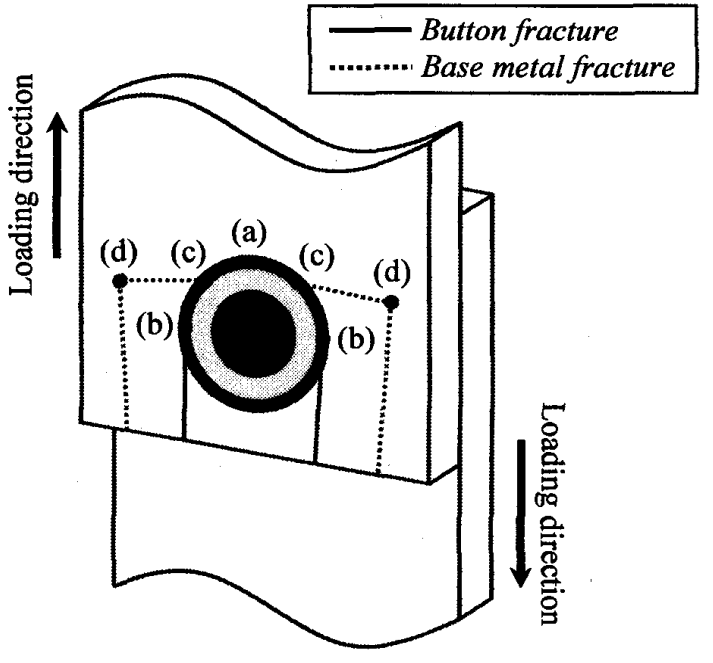

Fig. 6 Schematic illustration of fatigue crack propagation around welded spot in each fracture type

\section{Loading direction}

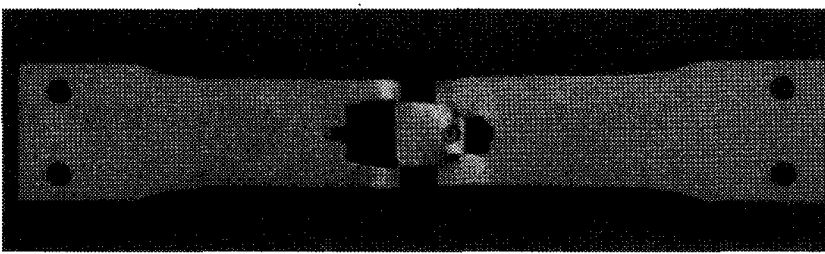

(a) Outward of the fracture specimen

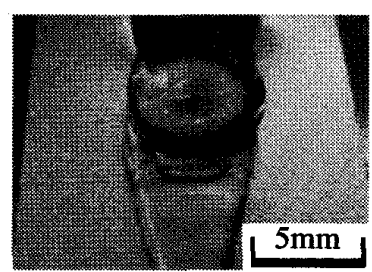

(b) Buttont fracture (c) Base metal fracture
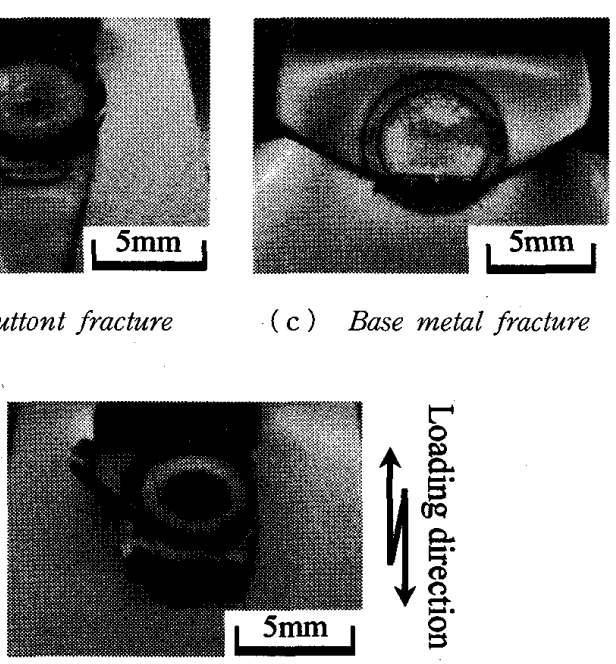

(d) Mixture fracture

Fig. 7 Observation of the fracture type 
破壊形態が混在した混合破壊が確認された。次節以降 それぞれの破壊形態について詳細な検討を行う。

\section{$3 \cdot 4$ ポタン破壊}

3・4・1 破面観察結果 走查型電子顕微鏡 (SEM) を用いてボタン破壊を呈した試験片破面の微視的観察 を行った。結果を図 8 に示す. 同図 (a)の模式図に示 すように，4種類に大別される破面様相が確認された。 第 1 段階として模式図 (I)の領域においてスポット部 周囲に板厚の半分程度までき裂が進展している領域が 確認された。なお，荷重軸方向スポット端部において 優先的にき裂が進展しており，荷重軸直角方向スポッ ト端部へ向かうにしたがって（Ｉ）の領域は減少してい ることが確認された．第 2 段階として模式図(II)の領 域において板厚の半分程度の高さを境界とし，（Ｉ）と 同様の疲労破面が観察された。

次に, (b ) に領域 (II) を荷重軸直角方向から観察 した結果を示す。同図より, 破面角度およびき裂進展 経路が急激に変化している部分が明瞭に確認されるこ とから（I）から（II）の領域へ遷移する過程においてき 裂進展挙動が変化したものと推察される. 第 3 段階と して模式図 (III)の領域において ( c )に示すように破面 が摩耗している領域が確認された。これれは,き裂の進 展による残余面積の減少に伴い供試体の変形量が大き くなった結果，き裂面が摺動したことに起因するもの と考えられる。なお，荷重軸垂直方向スポット端部へ 向かうに従って(III)の領域は増加していることが確認 された。最後に第 4 段階として模式図(IV)の領域にお
いて (d)に示すようにディンプル組織が確認されたこ とから，(IV)の領域においては静的な破壊を呈してい ると考えられる。

以上の結果より，負荷応力レベルが比較的高い場合， スポット部周辺に発生した疲労き裂は複数の複雑な進 展形態により成長していることが明らかとなった。

$3 \cdot 4 \cdot 2$ 三次元的疲労き裂進展挙動 これまで破 面の巨視的，および微視的観察から疲労き裂進展挙動 について検討したが, 疲労き裂は 2 枚の薄板の界面近 傍，すなわち試験片内部で発生，進展するため，より 詳細なき裂進展挙動の考察には試験片内部のき裂発 生, 進展挙動を三次元的に追う必要がある。そこで本 項では次に示す方法により，スポット部近傍に生じる 微小疲労き裂の三次元的観察を行った.まず, 破断寿 命に対して $x \%$ となる繰返し数で中断した試験片の スポット部近傍を切出し，樹脂埋めを施しバフ研磨， およびエッチング処理した断面を光学顕微鏡により観 察し 1 枚の観察画像を得る. その後, 荷重軸直角板幅 方向へ約 $0.2 \mathrm{~mm}$ 研削し, 同様の方法により観察画像 を得る.これを複数回繰返し，1つのサンプルより得 られた約 25 枚の断面観察画像から三次元グラフ作製 ソフトを用い，内部疲労き裂の三次元化を試みた。な

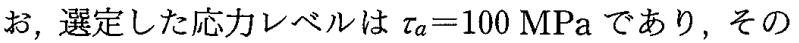
際，基準となる破断寿命 $N_{f}$ は同応力レベルにおいて 最も長寿命のもの $\left(N_{f}=12343\right.$ cycles $)$ とた.ここ で, $N / N_{f}=60 \%$ におる断面観察結果の一例および その略図を図 9 に示す。同図に示す通り，き裂はスリ

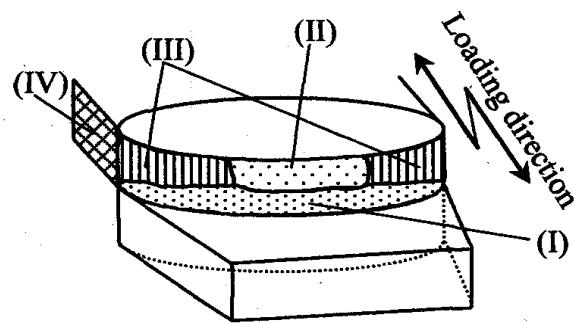

(a) Schematic illustration at welded spot

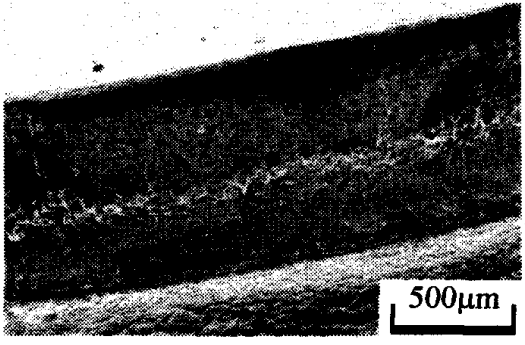

(b) Area I and II

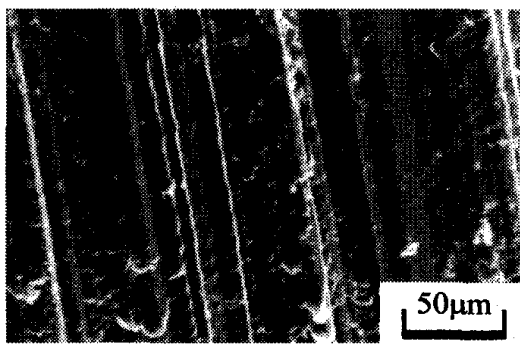

(c) Area III

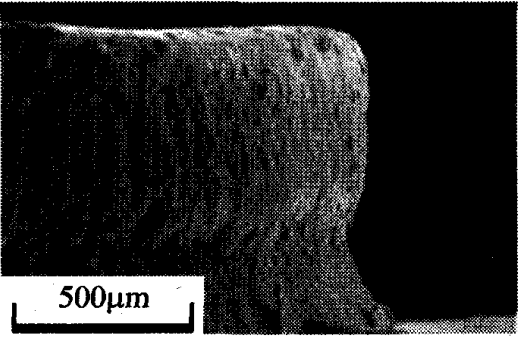

(b)' Fracture surface

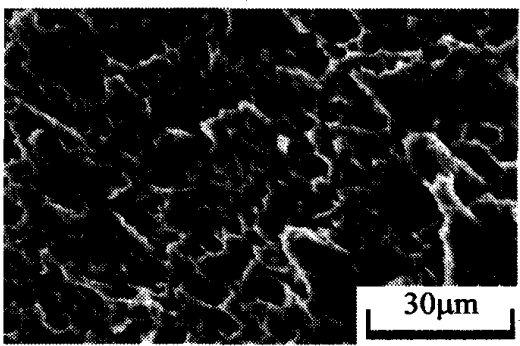

(d) Area IV

Fig. 8 Observation of the fracture surface (Button fracture) 
ット先端において発生しておう，荷重軸直角板厚方向 へ進展している様子がわかる。

それぞれの断面観察結果より得られた疲労き裂の三 次元化画像を図 10 に示す. 同図に示す通り, $N / N_{f}=$ $60 \%$ にいて荷重軸直角板厚方向へ $0.2 \mathrm{~mm}$ 程度き 裂が進展している様子が確認された。 なお， $N / N_{f}=$ 50\%においてはスポット部近傍にき裂は確認されなか った.これは，比較的高応力レベルでは全寿命に占め るき裂発生寿命の割合が大きいことを示唆するもので ある. その後, 繰返し数が増加するに従ってき裂は板 厚方向へ徐々に進展する様子が確認されるが, スポッ 卜端部中央が優先的に進展している様子がみられた $[(\mathrm{b}) \sim(\mathrm{d})]$.

3・4・3 ひずみ挙動次に，スポット部近傍のひ ずみ挙動から内部き裂進展挙動の推察を行うため, ス ポット部近傍にひずみゲージ［(株)共和産業製 単軸 $500 \Omega$, ゲージ長 $2 \mathrm{~mm}$ ）を貼付し, 繰返し負荷を受け た際の局所ひずみ值を測定した。ここで, 局所ひずみ とは面内曲げおよび引張りによって出力されるひずみ

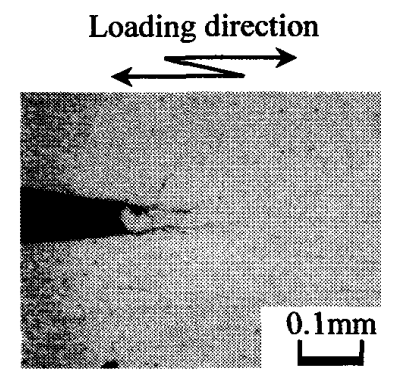

(a) Small fatigue crack at the left edge of slit

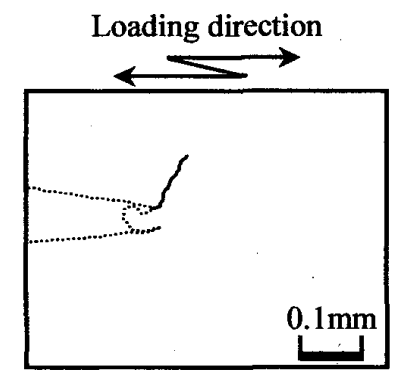

(b) Schematic illustration of ( $a$ )

Fig. 9 The small fatigue crack at the edge of slit $\left(\tau_{a}=\right.$ $100 \mathrm{MPa}$ )

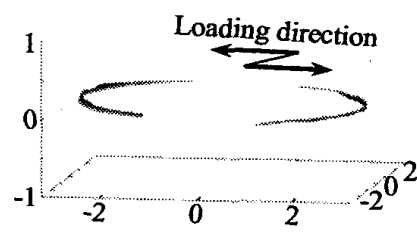

(a) $N / N_{f}=60 \%$

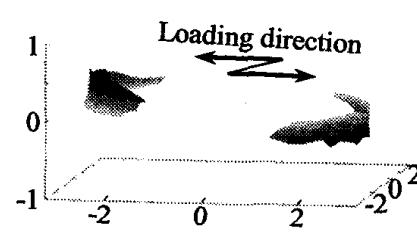

(c) $N / N_{f}=80 \%$

Fig. 10 3-D morphology of the fatigue crack propagation (Button fracture, unit : $\mathrm{mm}$ )
值の和と定義している．なお，ひずみゲージは図 11 に示すようにグリッド線の中心とスポット溶接部の中 心の距離が $6 \mathrm{~mm}$ となる位置に貼付した. 結果を図 12 に示す. 同図には最大, 最小のひずみ值, およびそ れらの差であるひずみ範囲を示している。き裂の発生 に伴いスポット部近傍のひずみ挙動が変化すると推察 されることから, 同図に扔けるひずみ範囲に着目する と, 破断寿命に対して 60\%程度の繰返し数から徐々に 上昇していることがわかる，これは前項で述べた三次 元的観察結果と同样の結果であり, 比較的高応力レべ ルに扔ける疲労き裂発生は非常に遅く，推定破断寿命 に対してき裂発生寿命が占める割合が比較的大きいこ とを裏付けるものである. 以上の結果, および前項の 結果から比較的高応力レベルにおいて, 本試験体はき 裂発生寿命が推定破断寿命に対して比較的高い割合を 占めることが明らかとなった。

\section{$3 \cdot 5$ 母材破壊}

$3 \cdot 5 \cdot 1$ 破面観察結果 母材破壊を呈した試験片 破面の微視的観察を行った結果を図 13 に示す.同図

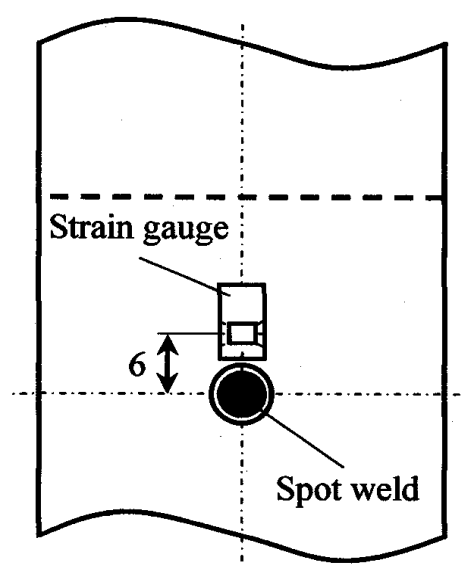

Fig. 11 Position of the strain gauge near the spot weld

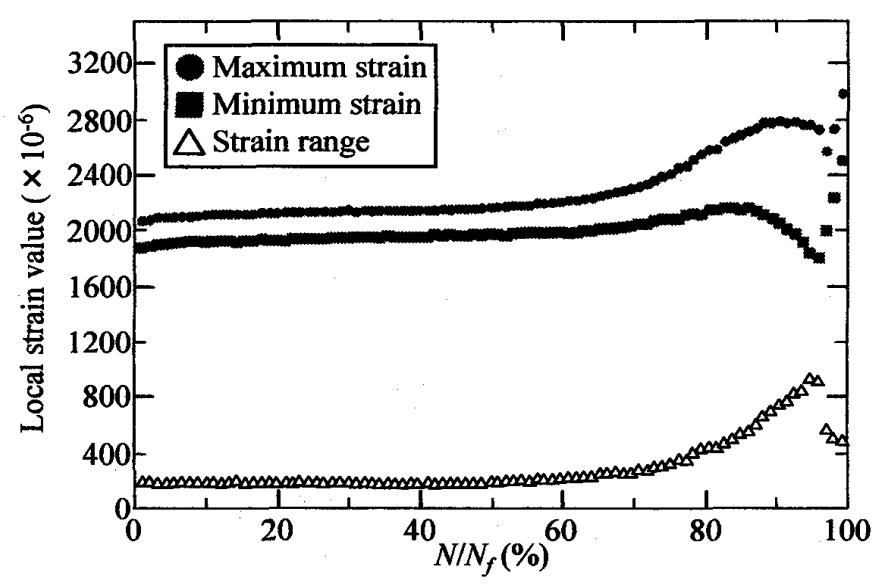

Fig. 12 Strain behavior around the welded spot (Button fracture) 


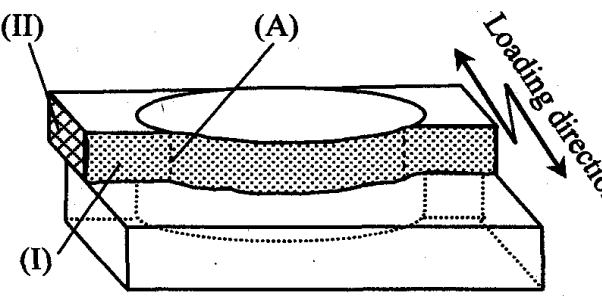

(a) Schematic illustration at welded spot

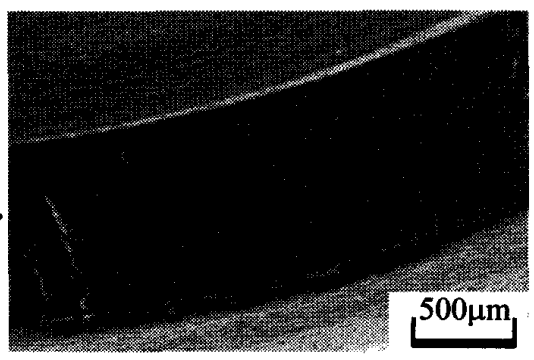

(b) Area I

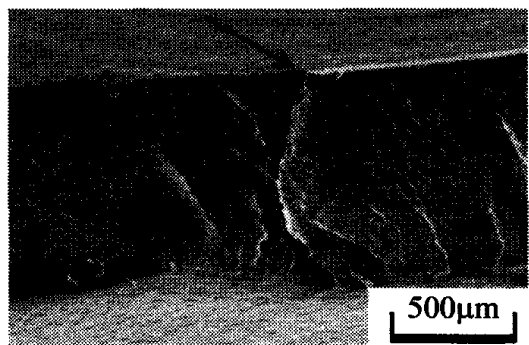

(c) Point A

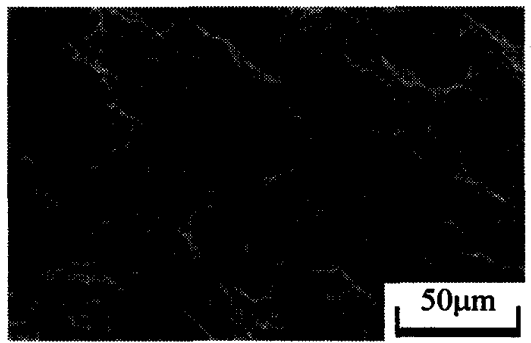

(d) Area II

Fig. 13 Observation of the fracture surface (Base metal fracture)

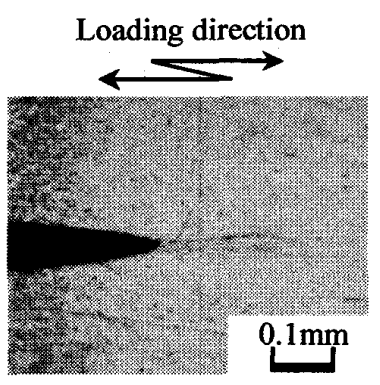

(a) Small fatigue crack at the left edge of slit

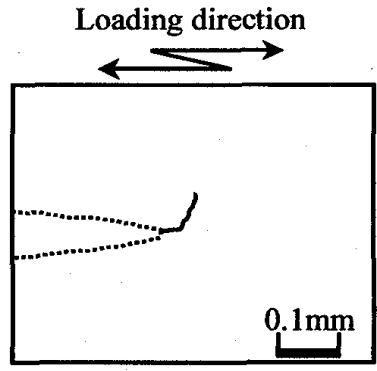

(b) Schematic illustration of ( a )

Fig. 14 The small fatigue crack at the edge of slit $\left(\tau_{a}=\right.$ $40 \mathrm{MPa}$ )

（a）の模式図に示すように 2 種類に大別される破面様 相が確認された。すなわち，一様な疲労破面 (領域 I ) と，静的破壊部(領域 II) である。な抢，同図（a）中の A 点近傍においてはスポット部周囲を進展するき裂 が，荷重軸直角方向へ進展経路を変えたき裂分岐点が 明確に確認される。

$3 \cdot 5 \cdot 2$ 三次元的疲労き裂進展挙動 前節と同様 の方法により，母材破壊に打ける疲労き裂進展挙動の 三次元的観察を行った。その際, 選定した応力レベル は $\tau_{a}=40 \mathrm{MPa}$ であり，最も長寿命であった破断絽返 し数 $\left(N_{f}=697510\right.$ cylces $)$ をいて整理している。 ス ポット中央部近傍の光学顕微鏡観察結果，およびその 略図を図 14 に, 得られた三次元的観察結果を図 $15 に$ それぞれ示す。

図 14 より前節のボタン破壞と同様, 母材破壊を呈

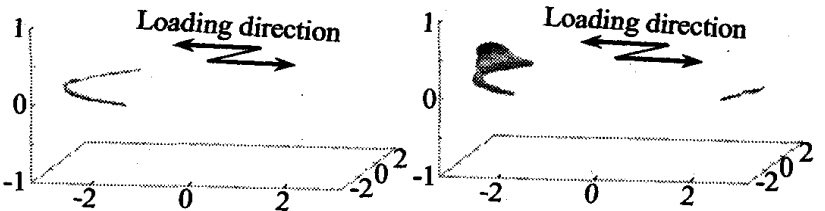

$\begin{array}{ll}\text { (a) } N / N_{f}=52 \% & \text { (b ) } N / N_{f}=54 \%\end{array}$

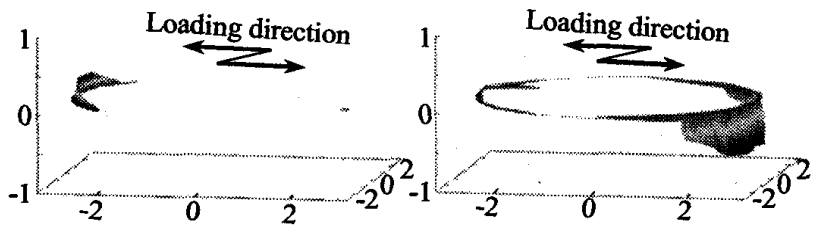

(c) $N / N_{f}=56 \%$

(d) $N / N_{f}=70 \%$

Fig. 15 3D morphology of the fatigue crack propagation (Base metal fracture, unit: $\mathrm{mm}$ )

する場合においてもき裂はスリット先端から発生して いることがわかる。 さらに，その後の進展挙動に着目

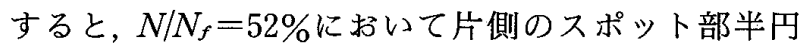
周上板厚方向に疲労き裂が $0.1 \mathrm{~mm}$ 程度進展してい る様子が確認された [図 15（a ）]。なお，N/Nf $=45 \%$ ではき裂は確認されなかったことから，比較的低応力 レベルにおいても，き裂発生寿命が全寿命に対して比 較的高い割合を占めることが推察される。

その後, 繰返し数の増加に伴い, き裂は荷重軸直角 板厚方向へ進展する様子が確認される[同図( b ), （c）,（d）］が, 母材破壊の場合, 前述したボタン破 壊とは異なり，片側のスポット周方向におけるき裂が 


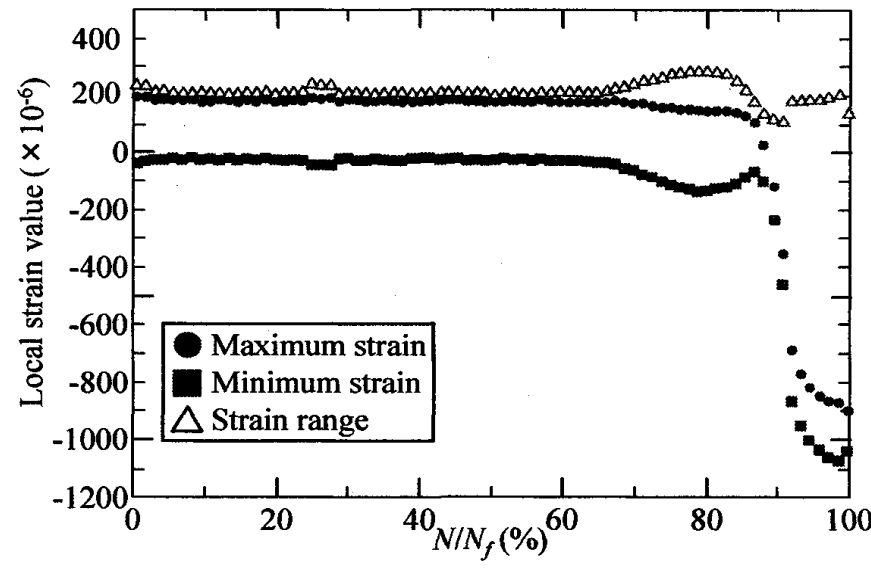

Fig. 16 Strain behavior around the welded spot (Base metal fracture)

優先的に進展する傾向にあることがわかる。

$3 \cdot 5 \cdot 3$ ひずみ挙動 母材破壊におけるスポット 部近傍のひずみ挙動を図 16 に示す。同図においてひ ずみ範囲に着目すると破断寿命に対して約 $60 \%$ 程度 の繰返し数にて挙動が変化していることがわかる. 先 に示したき裂の三次元的観察結果を考慮すると，き裂 発生に伴いひずみ挙動が変化したものと推察されるた め, 母材破壊の場合もボタン破壊と同様にき裂発生寿 命が推定破断寿命に対して比較的高い割合を占めるこ とがわかる。

以上の結果および前項の三次元的観察結果から, 比 較的低応力レベルにおいても高応力レベルと同様, き 裂発生寿命が推定破断寿命に対する割合が大きいこと が明らかとなった。

これまでの実験的考察より, スポット溶接継手近傍 に発生する疲労き裂は, そのき裂発生寿命が推定破断 寿命に対して占める割合が大きく，その起点は負荷応 カレベルによらずスリット端部であることが明らかと なったままた，巨視的な破壊形態には明らかな応力依 存性が確認されたものの, 内部の微視的な疲労き裂進 展挙動を詳細に観察した結果，母材破壊におけるき裂 分岐点に至るまでの挙動に限ると, 両破壊形態の疲労 き裂進展挙動に顕著な差異はないと言える。また, 前 述したように本試験体はき裂発生寿命が推定破断寿命 に対して高い割合を占めることを考慮すると，全寿命 の大部分において, 疲労き裂発生およびその進展挙動 に及ぼす負荷応力レベルの影響は少ないと考えられ る.したがって, 応力レベルによらず本試験体の疲労 特性を統一的に評価できる可能性が高いと考えられ る.

今後, 得られた疲労き裂進展挙動に基づいた三次元 FEM 解析により, き裂先端近傍の応力場について定
量的評価を行い, 本試験体の疲労特性の統一的評価手 法の確立を行う予定である。

\section{4. 結，言}

本研究では一般的自動車用鋼として用いられている 冷間圧延高張力鋼板 (SPFC590Y) を母材とするスポッ ト溶接継手を用い, スポット内部に生じる微小疲労き 裂に着目することで同材の疲労特性について実験的検 討を行った。以下に得られた結論を示す。

（1）本試験体の疲労強度は $30 \mathrm{MPa}$ 程度であり， 母材静的強度 $\left(\sigma_{y}=612 \mathrm{MPa}\right)$, および継手の静的強度 $\left(\sigma_{y}=480 \mathrm{MPa}\right)$ に比べ著しく低い值を示す.

（2）巨視的破壊形態には明らかな応力依存性が確 認された。すなわち, 比較的高応力レベルにおいては ボタン破壊が, 比較的低応力レベルにおいては母材破 壊が支配的である。

（3） スポット部周囲に発生する疲労き裂は, 負荷 される応力レベルによらず全破断寿命に対し, き裂発 生寿命が推定破断寿命に対しての割合が比較的大き w.

（4）全寿命の大部分において, 疲労き裂発生およ び進展挙動に及ほす負荷応力レベルの影響は少ないこ とが明らかとなった。すなわち，スポット溶接継手部 の疲労特性は負荷応力レベルによらず統一的に評価で きる可能性が高いと考えられる。

\section{文献}

(1) Omiya, Y., Sano, T. and Minoura, T., Latest Trends in Automobile Body Materials, Kobe Steel Engineering Reports, Vol. 57, No. 2 (2007), pp. 2-7.

(2) Nakanishi, E., High Strength Steel and Welding Technologies in Body Assemblies, Journal of the Japan Welding Society, Vol. 75, No. 6 (2006), pp. 525-527.

(3) Aoyama, S. and Fujimoto, M., Fatigue Strength of Spot Welded Specimens of Cold Rolled Steel Sheets, Journal of the Society of Materials Science, Japan, Vol. 24, No. 259 (1975), pp. 326-332.

(4) Yuuki, Y., Ohira, T., Nakatsukasa, H. and Won, Y., Fracture mechanics analysis and evaluation of the fatigue strength of spot welded joints, Transactions of the Japan Society of Mechanical Engineers, Series A, Vol. 51, No. 467 (1985), pp. 1772-1779.

(5) Fujimoto, M., Advanced approaches to fatigue life prediction on auto motive structures, [I] Why the fatigue strength of spot-welded structures should be studied, Journal of Society of Automotive Engineers of Japan, Vol. 40, No. 8 (1986), pp. 1048-1054.

(6) Mizui, M., Advanced approaches to fatigue life prediction on automotive structures, [II] Fatigue strength on spotwelded joints, Journal of Society of Automotive Engineers of Japan, Vol. 40, No. 9 (1986), pp. 12101217.

(7) Mabuchi, A. and Ohshima, M., Advanced approaches 
to fatigue life prediction on automotives structures, [III] Deformation and stress distribution in spotwelded members, Journal of Society of Automotive Engineers of Japan, Vol. 40, No. 10 (1986), pp. 13501358.

(8) Mori, N. and Mabuchi, A., Advanced approaches to fatigue life prediction on automotives structures, [IV] Analysis of loads acting on spot welds and its application to fatigue life prediction, Journal of Society of Automotive Engineers of Japan, Vol.40, No.11 (1986), pp. 1489-1497.

(9) Tsujimura, A. and Maeda, S., Advanced approaches to fatigue life prediction on automotive structures, [V] How strain measurement techniques can be applied to spot welds, Journal of Society of Automotive Engineers of Japan, Vol. 40, No. 12 (1986), pp. 1635-1643.

(10) Mori, N. and Amago, T., Local strain approaches to predict fatigue strength of spot-welded structures,
Transactions of the Japan Society of Mechanical Engineers, Series A, Vol. 55, No. 516 (1989), pp. 1716-1723.

(11) Li, C., Ohkura, K., Haranaka, K., Shinozaki, M. and Kitagawa, H., Relation between the Total Fatigue Life and the Fatigue Crack Initiation Life of a Spot Weld, Transactions of the Japan Society of Mechanical Engineers, Series A, Vol. 54, No. 505 (1988), pp. 1716-1722.

(12) Tohgo, K., Adomi, R., Araki, H., Syoko, K., Tanaka, H., Usuda, S. and Shimamura, Y., Influence of strength level of steels on fatigue strength and fatigue fracture mechanism of spot welded joints, Journal of the Society of Materials Science, Japan, Vol. 55, No. 12 (2006), pp. 1095-1101.

(13) Tohgo, K., Ohguma, T., Shimamura, Y. and Ojima, Y., FEM analysis study on fatigue strength and fracture morphology in spot welded joints of structural steels, Journal of the Society of Materials Science, Japan, Vol. 58, No. 7 (2009), pp. 627-634. 